\title{
Effect of dietary germinated sorghum on growth performance, carcass characteristics and some blood parameters of growing Japanese quails
}

\author{
Younis M. , Essa N. M., Abdo S. G. \\ Department of Animal and Poultry Production, Faculty of Agriculture, Al-Azhar University, 71524 Assiut, Egypt
}

\begin{abstract}
This study was carried out to evaluate the effect of germination in improving the nutritive value of grain sorghum and the effect of using germinated sorghum (GS) as partially or completely replacement of yellow corn in growing Japanese quail diets on growth performance, carcass characteristics and some blood parameters. A total number of two hundred and sixty-four 10-day-old Japanese quails were randomly distributed into four dietary treatment groups (each of 66), each treatment subdivided into 3 replicates (each of 22). Quail chicks in the first group fed corn-based diets ( $2922 \mathrm{kcal} / \mathrm{kg}$ feed and $24 \%$ crude protein) and served as control, while the chicks in the second, third and fourth groups received diets containing germinated sorghum as replacement of diet corn at levels 25,50 and 100\%, respectively. Results indicated that the inclusion of GS at all levels in growing Japanese quail diets had no significant effect on body weight, body gain, feed consumption, feed conversion ratio and carcass characteristics measured among all dietary treatments. Blood cholesterol decreased significantly in birds fed GS at levels 50 and $100 \%$ as replacement of yellow corn compared to the other birds. Nevertheless, triglyceride significant reduced in group of birds that fed dietary GS at level 100\% of yellow corn compared to the other groups. In conclusion, germinated sorghum could be safely incorporated in Japanese quail diets as replacement of yellow corn to improve growth rate and reduce the levels of serum cholesterol and triglyceride.
\end{abstract}

Keywords: germinated sorghum, quails, performance, carcass characteristics, blood parameters. 


\section{Introduction}

The major cost of poultry production is the feeding cost that can be $60-70 \%$ of the total production expenses. Energy sources as corn represents about 60 to $70 \%$ of the feed formulation. Thus, corn as an energy source represents about $50 \%$ of the total feed cost. The use of corn in livestock and poultry diets and its use as an alternative fuel in ethanol production has increased demand for corn, necessitating the exploration of other energy sources for livestock and poultry diets (Nyannor et al., 2015). Sorghum may be the next alternative to maize in poultry feed in terms of the nutritive value, cost and availability. Sorghum grain is the fifth most important cereal after wheat, rice, maize and barley worldwide in terms of both production and area planted (Popescu and Condei, 2014). The leading countries of sorghum production are the United States, Nigeria, Sudan, Mexico, Ethiopia, India, Argentina, China and Niger (FAO, 2017). The planted area of sorghum in Egypt is about 352410 feddan (feddan = 0.420 hectares $=1.037$ acres) produce 724 thousand tons with average yield 2.05 ton/feddan (CAPMAS, 2018). More than $70 \%$ of the area planted with sorghum is located in Assiut, Sohag and Fayoum (Afify et al., 2012). Sorghum grain contains about 8.9 - 15\% crude protein $(\mathrm{CP}), 2.8-5.3 \%$ fat, $1-2.5 \%$ ash, $1.5-4 \%$ crude fiber (CF) and $70-83 \%$ nitrogen free extract (NFE) on as fed basis (Raihanatu et al., 2011; Robertson and Perez-Maldonado, 2006; Shakouri et al., 2009; Tulasi et al., 2004). Therefore, it is comparable to corn grain in feeding value for poultry (Kumar et al., 2007;
Tyagi et al., 2003) and can reduce feed cost and dependency on maize. However, results are not always consistent because of the variable amounts of tannin present in different cultivars or varieties of sorghum (Emami et al., 2012). Bennick (2002) noticed that tannins have a number of effects on animals, including growth rate depression and inhibition of digestive enzymes. Hassan et al. (2003) reported that high tannin sorghum caused a highly significant reduction in the weight gain and feed intake of broiler chicks compared to low tannin sorghum and increased the feed conversion ratio. Germination is one of the traditional and simple methods for handling sorghum that could be reduce the levels of antinutritional organic factors, which including Phytates, Phenols, Tannins and enzyme inhibitors by releasing exogenous and endogenous enzymes such as Phytase enzyme formed during processing (Afify et al., 2012). Also, germination caused degradation of the stored nutrients like starch and protein to soluble sugars and free amino acids by hydrolytic enzymes to meet the seed requirements and the embryo growth (Yang et al., 2016). This makes it a beneficial processing technique for enhancing nutritive value of sorghum as result of its greatly influencing nutritional composition, bio-availability and utilization of nutrients (Singh et al., 2015). This study was carried out to evaluate the efficiency of germination method in improving the nutritive value of grain sorghum and to determine the effect of using germinated sorghum as replacement of yellow corn in diets of Japanese quails on body weight, body weight gain, feed consumption, feed conversion ratio, carcass characteristics and some blood parameters. 


\section{Materials and methods}

\subsection{Preparation of germinated sorghum}

Sorghum grain was cleaned from foreign matter and broken seed. The grains were soaked in $1: 2$ volumes of $0.2 \%$ formaldehyde solution for 40 minutes to prevent mold growth during germination. The soaked seeds were washed with tap water several times and re-soaked in water for 20 minutes to remove remaining formaldehyde. The wet grains were spread on trays lined with cloth and kept wet by frequent spraying of water at every morning and evening and allowed to germinate at room temperature for 72 hours. The grains after the removal of roots and shoots were sun dried, a representative sample of dry grains was taken and milled into fine flour and kept until analysis.

\subsection{Chemical analysis}

Ether extract, ash, total carbohydrate and total nitrogen (micro-Kjeldahl) of sorghum flour were determined according to A.O.A.C (1990). Protein was calculated as $\mathrm{N} \% \times 6.25$. Moisture content was determined by drying a sample at $105^{\circ} \mathrm{C}$ for 3 hours. Crude fiber content was determined according to the acid/alkali digestion method of Southgate (1976). The energy values of samples were calculated according to Pauzenga (1985) as follows:

$\mathrm{ME}=35 \times \mathrm{CP} \%+81.8 \times \mathrm{EE} \%+35.5 \times \mathrm{NFE} \%$.

2.3 Location, birds, diet, experimental design and managerial procedure

This study was carried out at Poultry Production Research Unite, Faculty of Agriculture, Al-Azhar University (Assiut branch), Assiut, Egypt, during May, 2018. A total number of two hundred and sixty four of 10-day-old Japanese quails were randomly distributed into four dietary treatments (66 birds for each treatment), each treatment subdivided into three replicates (22 birds for each replicate). All birds were housed in mesh wire cages $(100 \times 50 \times 30 \mathrm{~cm})$ with deep floor from straw. The bird in the first group were fed corn based diet $(2922 \mathrm{kcal} / \mathrm{kg}$ diet and $24 \%$ crude protein) and served as control, while birds in the second, third and fourth groups were fed diets contained germinated sorghum as replacement of corn at levels 25, 50 and $100 \%$, respectively, the formulation and chemical composition of all diets are shown in Table (1). A continuous lighting program was used 23h Light: 1h Dark along the experimental period, diet and water were offered ad libtium and temperature was performed according to standard managerial procedure.

\subsection{Parameters measured}

\subsubsection{Live Body weight and body weight gain}

Birds of each treatment were individually weighed weekly and body weight gain (BWG) was calculated according to the following equation:

$$
B W G=B W_{\text {week } n}-B W_{\text {week } n-1}
$$


Table (1): Ingredients and chemical analysis of the experimental diets for growing Japanese quail.

\begin{tabular}{lcccc}
\hline \multirow{2}{*}{ Ingredients } & \multicolumn{4}{c}{ Treatments } \\
\cline { 2 - 5 } & $\mathrm{T} 1$ & $\mathrm{~T} 2$ & $\mathrm{~T} 3$ & $\mathrm{~T} 4$ \\
\hline Yellow corn (8.5\%) & 57.74 & 43.31 & 28.87 & 0.0 \\
\hline Germinated sorghum & 0.0 & 14.43 & 28.87 & 57.74 \\
\hline Soy bean meal (48\%) & 27.77 & 27.77 & 27.77 & 27.77 \\
\hline Wheat fain bran & 3.2 & 3.2 & 3.2 & 3.2 \\
\hline Broiler Concentrates (52\%) & 9.4 & 9.4 & 9.4 & 9.4 \\
\hline Di calcium phosphate & 1.0 & 1.0 & 1.0 & 1.0 \\
\hline Limestone & 0.12 & 0.12 & 0.12 & 0.12 \\
\hline Vitamin and mineral mix1 & 0.3 & 0.3 & 0.3 & 0.3 \\
\hline DL-methionine & 0.12 & 0.12 & 0.12 & 0.12 \\
\hline Sodium chloride & 0.35 & 0.35 & 0.35 & 0.35 \\
\hline Total & 100 & 100 & 100 & 100 \\
\hline & Chemical analysis & & \\
\hline Crude protein, \% & 24.01 & 24.31 & 24.61 & 25.20 \\
\hline ME, Kcal/kg diet & 2922 & 2890 & 2858 & 2794 \\
\hline Curd fiber, \% & 2.88 & 2.75 & 2.61 & 2.07 \\
\hline Calcium, \% & 1.0 & 1.0 & 1.0 & 1.0 \\
\hline Total phosphorus, \% & 0.55 & 0.55 & 0.55 & 0.55 \\
\hline Methionine \& cystine, \% & 0.94 & 0.94 & 0.94 & 0.94 \\
\hline Lysine, \% & 1.29 & 1.29 & 1.28 & 1.28 \\
\hline
\end{tabular}

Each $3 \mathrm{~kg}$ of vitamin mineral premix: contains: vitamin A, 1200000IU; vitamin D3, 300000IU; vitamin E,700 $\mathrm{mg}$; vitamin K3, $500 \mathrm{mg}$; vitamin B1 $500 \mathrm{mg}$; vitamin B2 $200 \mathrm{mg}$; vitamin B6, $600 \mathrm{mg}$, vitamin B12, $3 \mathrm{mg}$; folic acid, $300 \mathrm{mg}$; choline chloride, $1000 \mathrm{mg}$; Niacin, $3000 \mathrm{mg}$; Methionine $3000 \mathrm{mg}$; Biotin $6 \mathrm{mg}$; panathonic acid $670 \mathrm{mg}$; manganese sulphat, $3000 \mathrm{mg}$; iron sulphat, $10000 \mathrm{mg}$, zinc sulphat, $1800 \mathrm{mg}$, copper sulphat $3000 \mathrm{mg}$, iodine $1.868 \mathrm{mg}$, cobalt sulphat, $300 \mathrm{mg}$; selenium, $0.108 \mathrm{mg}$. T1=Birds fed control diet. T2 $=$ Birds fed diets containing $25 \%$ germinated sorghum as replacement of corn. T3= Birds fed diets containing $50 \%$ germinated sorghum as replacement of corn. T4= Birds fed diets containing $100 \%$ germinated sorghum as replacement of corn.

\subsubsection{Feed consumption and feed conversion ratio}

Weekly feed consumption of each replicate was calculated by subtracting the weight of residual feed at the end of each week from the weight of the feed offered at the start of the week for each replicate. Feed conversion ratio (FCR) was calculated weekly by dividing the total feed consumed in each replicate by total BWG of the birds in the same replicate taking body weight gain of the mortalities into account.

$\mathrm{FCR}=$ feed, $\mathrm{g} /$ body weight gain, $\mathrm{g}$

\subsection{Blood sampling}

Approximately $3.0 \mathrm{~mL}$ of blood was collected in heparinized tube during slaughter (3 birds/ treatment); consequently, the serum was separated by centrifugation (10 mins. X $3000 \mathrm{rpm}$ ). Serum samples from each individual were divided into two samples in Eppendorf tubes and stored at $-20^{\circ} \mathrm{C}$ for later analyses. Frozen sera was thawed at room temperature and assayed for total protein, albumin, cholesterol, triglycerides and glucose using kits from Spectrum Diagnostics, Egypt. 


\subsection{Carcass characteristics}

At the end of the experiment 3 males selected from each treatment around average body weight of the treatment. The Selected chicks were fasted for 12 hours prior termination then all males were slaughtered to evaluate the carcass Characteristics and the impact of dietary treatments on the internal organs (heart, liver, spleen, gizzard, proventriculus, testes and Small intestine).

\subsection{Statistics analysis}

Data was statistically analyzed by Analysis of Variance (ANOVA) using the General Liner Model (GLM) of SAS (2009). Significant differences among treatment means were separated by Duncan's multiple rang test (Duncan, $1955)$ with a $5 \%$ level of probability. All data obtained was analyzed by using the following model:

$\mathrm{Yij}=\mu+\mathrm{Ti}+\mathrm{eij}$

Where; Yij and yijk $=$ the analyzed measurement. $\mu=$ is the overall mean, $\mathrm{Ti}$ $=$ is the effect of germinated sorghum feeding treatments $(\mathrm{i}=0.0,25,50$ and $100 \%)$. eij $=$ random error.

\section{Results and Discussion}

\subsection{Nutrient composition of germinated sorghum}

The chemical composition of raw and germinated sorghum are shown in (Table 2 ). The results of the chemical analysis revealed that raw sorghum grains contained $9.32 \%$ crude protein, $4.87 \%$ ether extract, $1.11 \%$ crude fiber, $72.22 \%$ nitrogen-free extract and $1.9 \%$ ash. These results are agreement with Yang et al. (2016) who reported that grain sorghum contained $9.99 \%$ crude protein, $4.74 \%$ crude fat and $69.42 \%$ starch. Germination of sorghum for 72 hours significantly increased the contents of moisture, crude protein, crude fiber and ash. While significantly reduced the contents of dry matter, organic matter, ether extract and nitrogen free extract compared to raw sorghum grains. These results are completely agreement with Warle et al. (2015) who noted that the germination of sorghum grains for 72 hours significantly increased the contents of moisture, crude protein and crude fiber. While, significantly reduced the contents of dry matter, organic matter, fat and nitrogen free extract. Narsih et al. (2012) suggested that the increase of protein content during germination process due to the presence of synthesis processes and reduced of dry matter in the process of soaking. While, the reduce of fat content its due to lipolytic enzyme activated during germination and hydrolyze fat into fatty acid and glycerol. Also, Yang et al. (2016) reported that Fat content decreased during germination, because germinated seeds need another source of energy rather than sugars which have been already utilized. The decrease in carbohydrate content of germinated sorghum may be due to utilization of some sugars during the growth metabolic activity (Okporo et al., 2015 and Nour et al., 2015). An increase in ash content is considered to be apparently caused by the loss of starch (Singh et al., 2015). 
Table (2): Effect of germination process on the chemical composition of sorghum grains $(\bar{x} \pm \mathrm{SE})$.

\begin{tabular}{lccc}
\hline Items & Row sorghum & Germinated sorghum & Sign \\
\hline Moisture & $9.58 \pm 0.09^{\mathrm{b}}$ & $13.5 \pm 0.13^{\mathrm{a}}$ & $* *$ \\
\hline Dry matter & $90.4 \pm 0.09^{\mathrm{a}}$ & $86.5 \pm 0.13^{\mathrm{b}}$ & $* *$ \\
\hline Crud protein & $9.32 \pm 0.09^{\mathrm{b}}$ & $10.86 \pm 0.11^{\mathrm{a}}$ & $* *$ \\
\hline Ether extract & $4.87 \pm 0.19^{\mathrm{a}}$ & $3.72 \pm 0.11^{\mathrm{b}}$ & $*$ \\
\hline Crud fiber & $1.04 \pm 0.06^{\mathrm{b}}$ & $1.26 \pm 0.04^{\mathrm{a}}$ & $*$ \\
\hline Ash & $1.69 \pm 0.05^{\mathrm{b}}$ & $1.82 \pm 0.02^{\mathrm{a}}$ & $*$ \\
\hline Organic matter & $88.7 \pm 0.14^{\mathrm{a}}$ & $84.7 \pm 0.13^{\mathrm{b}}$ & $* *$ \\
\hline Nitrogen free extract & $73.5 \pm 0.25^{\mathrm{a}}$ & $68.9 \pm 0.11^{\mathrm{b}}$ & $* *$ \\
\hline${ }_{\mathrm{a} \& \mathrm{~b}}$ Means with the same letter within rows are not significantly different. & $*=$ probability \\
$(\mathrm{P}<0.05) . * *=$ probability $(\mathrm{P}<0.01)$.
\end{tabular}

\subsection{Growth performance}

The results of weekly body weight and body weight gain are presented in Table (3). The results indicated that the inclusion of germinated sorghum in diets of growing Japanese quails at levels 25, 50 and $100 \%$ had no effect $(\mathrm{P}>0.05)$ on body weight during the period from 10 to 38 days of age. Also, there was no significant $(\mathrm{P}>0.05)$ effect on body weight gain of Japanese quails during the first two weeks of the experiment. During the $3^{\text {rd }}$ week of experiment, birds that received germinated sorghum at level $100 \%$ recorded the lowest $(\mathrm{P}<0.01)$ body weight gain compared the other treatments. During the $4^{\text {th }}$ week of experiment, the highest $(\mathrm{P}<0.01)$ body weight gain was found in group that received germinated sorghum at level $25 \%$ while the lowest $(\mathrm{P}<0.01)$ was found in those fed germinated sorghum at level $50 \%$. However, body weight gain did not show significant $(\mathrm{P}>0.05)$ differences among all dietary treatments. The previous results are agreement with Younis et al. (2012) who found no significant difference between body weight and body weight gain of two quail strains (Black and brown) that fed diets containing germinated sorghum at levels $25,50,75$ and $100 \%$ of yellow corn. Also, Maidala et al. (2016) found no significant differences in the body weight gain of broiler chicks that fed corn based diet or these fed germinated sorghum based diets. The results of weekly feed consumption and feed conversion ratio are presented in Table (4). No significant $(\mathrm{P}>0.05)$ difference was observed in feed consumption among all dietary treatments during the experiment period. Also, no significant differences were found in feed conversion ratio among all dietary treatment during the first two weeks of the experiment. During the period from 24 to 31 days of age, birds fed dietary SG, $50 \%$ of yellow corn recorded the best $(\mathrm{P}<0.05)$ FCR, however, during the period from 31 to 38 days of age, the best $(\mathrm{P}<0.0)$ FCR was recorded for birds fed dietary GS, $25 \%$ of yellow corn and control diet compared with other dietary treatments. No significant differences were observed in the overall mean of feed conversion ratio among all dietary treatments. 
Table (3): Effect of dietary germinated sorghum on body weight and body weight gain of Japanese quails $(\overline{\mathrm{x}} \pm \mathrm{SE})$.

\begin{tabular}{|c|c|c|c|c|c|}
\hline \multirow{2}{*}{ Age } & \multicolumn{4}{|c|}{ Treatments } & \multirow{2}{*}{ Sign } \\
\hline & $\mathrm{T} 1$ & $\mathrm{~T} 2$ & T3 & $\mathrm{T} 4$ & \\
\hline \multicolumn{6}{|c|}{ Live body weight } \\
\hline 10 day & $38.0 \pm 0.72$ & $37.9 \pm 0.70$ & $37.8 \pm 0.79$ & $38.0 \pm 0.73$ & Ns \\
\hline 17 day & $73.4 \pm 1.42$ & $74.6 \pm 1.41$ & $74.6 \pm 1.52$ & $76.0 \pm 1.36$ & Ns \\
\hline 24 day & $124.2 \pm 2.10$ & $125.0 \pm 2.05$ & $122.8 \pm 2.10$ & $126.9 \pm 1.97$ & Ns \\
\hline 31 day & $170.7 \pm 2.48$ & $173.5 \pm 2.43$ & $170.5 \pm 2.45$ & $170.9 \pm 2.06$ & Ns \\
\hline 38 day & $205.5 \pm 2.76$ & $209.9 \pm 2.87$ & $202.2 \pm 2.70$ & $206.0 \pm 2.33$ & Ns \\
\hline \multicolumn{6}{|c|}{ Body weight gain } \\
\hline 10-17 day & $35.36 \pm 0.74$ & $36.63 \pm 0.76$ & $36.64 \pm 0.79$ & $38.01 \pm 0.69$ & Ns \\
\hline 17-24 day & $50.75 \pm 0.87$ & $50.70 \pm 0.78$ & $48.33 \pm 1.03$ & $50.69 \pm 0.74$ & Ns \\
\hline 24-31 day & $46.50 \pm 0.60^{\mathrm{a}}$ & $47.66 \pm 0.79^{\mathrm{a}}$ & $47.80 \pm 0.69^{\mathrm{a}}$ & $43.94 \pm 0.50^{b}$ & $* *$ \\
\hline 31-38 day & $34.78 \pm 0.76^{b}$ & $37.73 \pm 0.83^{\mathrm{a}}$ & $32.20 \pm 0.69^{c}$ & $34.97 \pm 0.66^{b}$ & $* *$ \\
\hline Overall mean & $41.88 \pm 0.57$ & $43.26 \pm 0.54$ & $41.21 \pm 0.59$ & $41.96 \pm 0.50$ & Ns \\
\hline
\end{tabular}

${ }_{a}$, b\&c Means with same letters within rows are not significant different $(p>0.05)$. Ns $=$ non-significant means. $* *=$ probability $(\mathrm{P}<0.01)$. $\mathrm{T} 1=\mathrm{Birds}$ fed control diet. $\mathrm{T} 2=$ Birds fed diets containing $25 \%$ germinated sorghum as replacement of corn. T3= Birds fed diets containing $50 \%$ germinated sorghum as replacement of corn. T4= Birds fed diets containing $100 \%$ germinated sorghum as replacement of corn.

Table (4): Effect of feeding dietary germinated sorghum on feed consumption and feed conversion ratio of Japanese quails $(\bar{x} \pm S E)$.

\begin{tabular}{|c|c|c|c|c|c|}
\hline \multirow{2}{*}{ Age } & \multicolumn{4}{|c|}{ Treatments } & \multirow{2}{*}{ Sign } \\
\hline & $\mathrm{T} 1$ & $\mathrm{~T} 2$ & T3 & $\mathrm{T} 4$ & \\
\hline \multicolumn{6}{|c|}{ Feed consumption (g/bird/Week) } \\
\hline 10-17 day & $73.83 \pm 1.50$ & $77.85 \pm 1.14$ & $73.96 \pm 0.46$ & $74.06 \pm 1.06$ & Ns \\
\hline 17-24 day & $133.6 \pm 5.34$ & $133.9 \pm 1.89$ & $129.1 \pm 5.90$ & $132.1 \pm 1.96$ & Ns \\
\hline 24-31 day & $156.2 \pm 5.29$ & $163.3 \pm 4.60$ & $155.1 \pm 0.75$ & $155.0 \pm 1.89$ & Ns \\
\hline 31-38 day & $184.6 \pm 4.00$ & $185.7 \pm 4.09$ & $177.2 \pm 5.51$ & $189.7 \pm 3.56$ & Ns \\
\hline 10-38 day & $547.7 \pm 2.80$ & $560.2 \pm 1.85$ & $535.1 \pm 2.13$ & $550.5 \pm 0.95$ & Ns \\
\hline \multicolumn{6}{|c|}{ Feed conversion ratio ( $\mathrm{g}$ feed/ g gain) } \\
\hline 10-17 day & $2.16 \pm 0.06$ & $2.22 \pm 0.08$ & $2.08 \pm 0.05$ & $2.0 \pm 0.05$ & NS \\
\hline 17-24 day & $2.68 \pm 0.05$ & $2.68 \pm 0.04$ & $2.73 \pm 0.05$ & $2.64 \pm 0.05$ & Ns \\
\hline 24-31 day & $3.39 \pm 0.05^{\mathrm{ab}}$ & $3.46 \pm 0.05^{\mathrm{ab}}$ & $3.33 \pm 0.07^{\mathrm{b}}$ & $3.55 \pm 0.04^{\mathrm{a}}$ & $*$ \\
\hline 31-38 day & $5.48 \pm 0.14^{\mathrm{ab}}$ & $5.12 \pm 0.16^{b}$ & $5.64 \pm 0.12^{\mathrm{a}}$ & $5.55 \pm 0.12^{\mathrm{a}}$ & $*$ \\
\hline $\begin{array}{l}\text { Overall } \\
\text { mean }\end{array}$ & $3.31 \pm 0.05$ & $3.29 \pm 0.05$ & $3.29 \pm 0.05$ & $3.31 \pm 0.03$ & Ns \\
\hline
\end{tabular}

\subsection{Carcass characteristics}

The weights and percentages of edible parts of Japanese quail (liver, heart and gizzard), organs (spleen, small intestine and testes) and dressing are presented in (Table 5). The results of weight and percentage of edible parts, organs and carcass dressing showed no significant 
$(\mathrm{P}>0.05)$ differences among all dietary treatments. The present results are agreement with (Al-Mashehadani, 2016) who found no significant differences in the percentage of edible parts and carcass dressing between groups of broiler chicks that fed germinated sorghum or corn based diets.

Table (5): Effect of feeding dietary germinated sorghum grain on weight and percentage of edible parts, organs and dressing of japanese quails $(\overline{\mathrm{x}} \pm \mathrm{SE})$.

\begin{tabular}{|c|c|c|c|c|c|}
\hline \multirow[b]{2}{*}{ Items } & \multicolumn{4}{|c|}{ Treatments } & \multirow[b]{2}{*}{ sign } \\
\hline & $\mathrm{T} 1$ & $\mathrm{~T} 2$ & T3 & $\mathrm{T} 4$ & \\
\hline \multicolumn{6}{|c|}{ Weight (g) } \\
\hline Live body weight & $199.4 \pm 1.42$ & $194.9 \pm 2.72$ & $199.4 \pm 2.13$ & $198.3 \pm 2.33$ & Ns \\
\hline Heart & $1.63 \pm 0.08$ & $1.57 \pm 0.03$ & $1.75 \pm 0.10$ & $1.59 \pm 0.095$ & Ns \\
\hline Liver & $4.43 \pm 0.34$ & $4.45 \pm 0.45$ & $4.77 \pm 0.28$ & $4.16 \pm 0.09$ & Ns \\
\hline Gizzard & $3.73 \pm 0.29$ & $3.34 \pm 0.16$ & $3.27 \pm 0.09$ & $3.01 \pm 0.055$ & Ns \\
\hline Spleen & $0.12 \pm 0$ & $0.11 \pm 0.01$ & $0.13 \pm 0.03$ & $0.10 \pm 0.01$ & Ns \\
\hline Small intestine & $7.22 \pm 1.04$ & $8.66 \pm 0.78$ & $9.74 \pm 1.25$ & $9.06 \pm 1.10$ & Ns \\
\hline Testes & $2.26 \pm 0.18$ & $2.61 \pm 0.80$ & $2.76 \pm 0.04$ & $2.24 \pm 0.60$ & Ns \\
\hline Dressing & $142.8 \pm 1.85$ & $137.1 \pm 0.61$ & $138.3 \pm 1.25$ & $139.7 \pm 2.24$ & Ns \\
\hline \multicolumn{6}{|c|}{ Percentage $(\%)$} \\
\hline Heart & $0.82 \pm 0.04$ & $0.81 \pm 0.02$ & $0.88 \pm 0.06$ & $0.80 \pm 0.06$ & Ns \\
\hline Liver & $2.22 \pm 0.18$ & $2.28 \pm 0.20$ & $2.40 \pm 0.15$ & $2.10 \pm 0.07$ & Ns \\
\hline Gizzard & $1.87 \pm 0.13$ & $1.71 \pm 0.09$ & $1.64 \pm 0.032$ & $1.52 \pm 0.03$ & Ns \\
\hline Spleen & $0.06 \pm 0.00$ & $0.06 \pm 0.01$ & $0.07 \pm 0.01$ & $0.05 \pm 0.00$ & Ns \\
\hline Small intestine & $3.62 \pm 0.52$ & $4.43 \pm 0.34$ & $4.87 \pm 0.57$ & $4.57 \pm 0.54$ & Ns \\
\hline Testes & $1.14 \pm 0.10$ & $1.33 \pm 0.40$ & $1.39 \pm 0.03$ & $1.14 \pm 0.31$ & Ns \\
\hline Dressing & $71.62 \pm 0.46$ & $70.35 \pm 0.78$ & $69.37 \pm 0.63$ & $70.48 \pm 0.70$ & Ns \\
\hline
\end{tabular}

Ns = non- significant mean. T1=Birds fed control diet. T2 = Birds fed diets containing $25 \%$ germinated sorghum as replacement of corn. T3= Birds fed diets containing $50 \%$ germinated sorghum as replacement of corn. T4= Birds fed diets containing $100 \%$ germinated sorghum as replacement of corn.

\subsection{Blood parameters}

Data regarding some blood parameters expressed as percentage of; total protein, albumin, globulin, $\mathrm{A} / \mathrm{G}$ ratio, Triglyceride and cholesterol are presented in Table (6). The feeding of Japanese quail on different levels of germinated sorghum had no effect $(\mathrm{P}>0.05)$ on the levels of serum total protein, albumen, globulin, $\mathrm{A} / \mathrm{G}$ ratio and glucose. Inclusion of germinated sorghum in Japanese quail diet at level $100 \%$ of yellow corn significantly
$(\mathrm{P}<0.05)$ reduced the level of Triglycerides compared the other treatments. Also, serum cholesterol decreased $(\mathrm{P}<0.05)$ significantly for birds fed germinated sorghum at levels 50 and $100 \%$ of yellow corn compared to the other treatments. These results are in agreement with Fafiolu et al. (2006) who reported that the higher levels of malted sorghum sprouted inclusion in the diets show a corresponding reduction in triglyceride and cholesterol. Also, Ahmed et al. (2017) indicated a significantly 
$(\mathrm{p}<0.05)$ decrease on cholesterol content germinated sorghum compared to those in whole blood serum of birds fed on fed un-germinated sorghum.

Table (6): Effect of feeding dietary germinated sorghum grain on some blood parameters of growing Japanese quail $(\overline{\mathrm{x}} \pm \mathrm{SE})$.

\begin{tabular}{lccccc}
\hline \multirow{2}{*}{ Blood parameters } & \multicolumn{5}{c}{ Treatments } \\
\cline { 2 - 6 } & $\mathrm{T} 1$ & $\mathrm{~T} 2$ & $\mathrm{~T} 3$ & $\mathrm{~T} 4$ & Sign \\
\hline Total protein & $4.36 \pm 0.11$ & $4.53 \pm 0.14$ & $4.49 \pm 0.07$ & $4.77 \pm 0.10$ & $\mathrm{Ns}$ \\
\hline Albumen $(\mathrm{A})$ & $2.25 \pm 0.20$ & $2.41 \pm 0.12$ & $2.56 \pm 0.16$ & $2.43 \pm 0.09$ & $\mathrm{Ns}$ \\
\hline Globulin $(\mathrm{G})$ & $2.11 \pm 0.17$ & $2.12 \pm 0.20$ & $1.93 \pm 0.17$ & $2.34 \pm 0.12$ & $\mathrm{Ns}$ \\
\hline $\mathrm{A} / \mathrm{G}$ & $1.15 \pm 0.23$ & $1.28 \pm 0.20$ & $1.48 \pm 0.24$ & $1.07 \pm 0.09$ & $\mathrm{Ns}$ \\
\hline Triglyceride & $196.8 \pm 4.09 \mathrm{a}$ & $199.7 \pm 2.62 \mathrm{a}$ & $189.2 \pm 6.08 \mathrm{a}$ & $175.5 \pm 2.59 \mathrm{~b}$ & $*$ \\
\hline Cholesterol & $185.7 \pm 1.94 \mathrm{a}$ & $187.7 \pm 3.34 \mathrm{a}$ & $170.2 \pm 4.15 \mathrm{~b}$ & $165.6 \pm 4.73 \mathrm{~b}$ & $*$ \\
\hline Glucose & $120.9 \pm 2.64$ & $121.8 \pm 4.75$ & $123.6 \pm 3.37$ & $116.7 \pm 3.77$ & $\mathrm{Ns}$ \\
\hline
\end{tabular}

${ }^{\mathrm{a} \& \mathrm{~b}}$ Means with same letters within rows are not significant different $(\mathrm{p}>0.05)$. Ns $=$ non- significant mean. $*=$ probability $(\mathrm{P}<0.05)$. T1=Birds fed control diet. $\mathrm{T} 2=$ Birds fed diets containing $25 \%$ germinated sorghum as replacement of corn. T3= Birds fed diets containing 50\% germinated sorghum as replacement of corn. T4= Birds fed diets containing $100 \%$ germinated sorghum as replacement of corn.

\section{Conclusions}

Germinated sorghum could be safely incorporated in Japanese quail diets as replacement of yellow corn with no negative effect on growth rate and carcass characteristics. Germinated sorghum significantly reduce the levels of serum cholesterol and triglyceride.

\section{References}

A.O.A.C. (1990), Official Methods of Analysis, $15^{\text {th }}$ ed., Association of Official Analytical Chemists, Washington, DC, USA.

Afify, A. E. M., El-Beltagi, H. S., Abd El-Salam, S. M. and Omran, A. A. (2012), "Protein solubility, digestibility and fractionation after germination of sorghum varieties", PLOS ONE, Vol. 7, pp. 2.

Ahmed, O. E., Salih, M. E., and Mohammed, K. A. (2017),"Effect of reducing phytic acid from sudanese sorghum bicolor (f.g) using simple technique methods on broilers performance", International Journal of Research Studies in Agricultural Sciences, Vol. 3 No. 11, pp. 18-30.

Al-Mashhadani, H. A. (2016), "The effect of partial and complete replacement of raw and germination sorghum for yellow corn in broiler rations in some productive and physiological traits", Journal of Kerbala University, Vol. 14 No. 2, pp. 30-40.

Bennick, A. (2002), "Interaction of plant polyphenols with salivary proteins", Critical Reviews in Oral Biology \& 
Medicine, Vol. 13 No. 2, pp. 184196.

CAPMAS, (2018), Annual bulletin of cropping areas and vegetable production, statistics 2015/2016, Central Agency for Public Mobilization and Statistics, Cairo, Egypt.

Duncan, D. B. (1955), "Multiple Range and Multiple F Tests", International Biometric Society, Vol. 11 No. 1, pp. 1-42.

Emami, F., Maheri-Sis, N., Ghorbani, A. and Vahdatpour, T. (2012), "Effects of feeding untreated or reconstituted sorghum grain (Sorghum bicolor L.) on growth performance of Japanese quails (Coturnix japonica)", International Journal of Biosciences, Vol. 2 No. 12, pp. 3137.

Fafiolu, A. O., Oduguwa, O. O., Ikeobi, C. O. and Onwuka, C. F. (2006), "Utilization of malted sorghum sprout in the diet of rearing pullets and laying hens", Archivos de Zootecnia, Vol. 55 No. 212, pp. 361-371.

FAO (2017), Food and Agriculture Organization of United Nations, FAOSTAT Database, Retrieved April 26, 2019, from http://www.fao.org/faostat/en/\#ranki ngs/commodities_by_country_impor ts.

Hassan, I. A., Elzubeir, E. A. and El
Tinay, A. H. (2003), "Growth and apparent absorption of minerals in broiler chicks fed diets with low or high tannin contents", Tropical Animal Health and Production, Vol. 35 No. 2, pp. 189-196.

Kumar, V., Elangovan, A. V., Mandal, A. B., Tyagi, P. K., Bhanja, S. K. and Dash, B. B. (2007), "Effects of feeding raw or reconstituted high tannin red sorghum on nutrient utilisation and certain welfare parameters of broiler chickens", British Poultry Science, Vol. 48 No. 2, pp. 198-204.

Maidala, A., Bakoshi, A. M. and Gumai, S. A. (2016), "Growth performance and economics of production of broiler chickens fed three partially sprouted sorghum varieties as a replacement for Maize", Journal of Biology and Genetic Research, Vol. 2 No. 3, pp. 8-16.

Narsih, A., Yunianta, S. and Harijono, H. (2012), "The study of germination and soaking time to improve nutritional quality of sorghum seed", International Food Research Journal, Vol. 19 No. 4, pp. 14291432.

Nour, A. A., Ibrahim, M. A., Abdelrhman, E. E. and Osman, E. F. (2015), "Effect of processing methods on nutritional value of sorghum (Sorghum bicolor L. Moench) cultivar", American Journal of Food Science and Health, Vol. 1 No. 4, pp. 104-108. 
Nyannor, E. K. D., Adedokun, S. A., Hamaker, B. R., Ejeta, G. and Adeola, O. (2007), "Nutritional evaluation of high-digestible sorghum for pigs and broiler chicks", Journal of Animal Science, Vol. 85 No. 1, pp. 196-203.

Okporo, E. V., Ameh, D. A., Sallau, A. B. and Aba, D. A. (2016), "Effect of malting on chemical composition and protein in vitro digestibility of three new varieties of sorghum grains", International Journal of Science and Research, Vol. 5 No. 7, pp. 2107-2110.

Pauzenga, O. (1985), "Feeding parent stock", Zootechnical International, Vol. 22, pp. 22-24.

Popescu, A. and Condei, R. (2014), "Some considerations on the prospects of sorghum crop", Economic Engineering in Agriculture and Rural Development, Vol. 14 No. 3, pp. 295-304.

Raihanatu, M. B., Modu, S., Falmata, A. S., Shettima, Y. A. and Heman, M. (2011), "Effect of processing (sprouting and fermentation) of five local varieties of sorghum on some biochemical parameters", Biochemistry, Vol. 23 No. 2, pp. 9196.

Robertson, S. K. and Perez-Maldonado, R. A. (2006), "Nutritional characteristics of sorghums from QLD and NSW", Proceedings of the $18^{\text {th }}$ Australian Poultry Science
Symposium, Poultry Research Foundation, Sydney, New South Wales, Australia, pp. 49-52.

SAS Institute (2009), The User's Guide to Statistics with JMP Student Edition; Using JMP Student Edition for Windows and Macintosh, SAS Institute Inc., Cary, North Carolina, USA.

Shakouri, M. D., Iji, P. A., Mikkelsen, L. L. and Cowieson, A. J. (2009), "Intestinal function and gut microflora of broiler chickens as influenced by cereal grains and microbial enzyme supplementation", Journal of Animal Physiology and Animal Nutrition, Vol. 93 No. 5, pp. 647-658.

Singh, E., Jain, P. K. and Sharma, S. (2015), "Effect of different household processing on nutritional and anti-nutritional factors in Vigna aconitifolia and Sorghum bicolour (L.) Moench seeds and their product development", Journal of Medical Nutrition and Nutraceuticals, Vol. 4 No. 2, pp. 95-100.

Southgate, D. A. T. (1976), "The analysis of dietary fiber", Fiber in human nutrition, Spiller, G. A. and Amen R. J. (Eds), Plenum Press, New York, USA, pp. 73-103.

Tulasi, S. L., Reddy, A. R., Reddy, G. R., Prasad, V. L. K., Raju, M. V. L. N., Rao, C. L. N., Reddy, B. V. S., Rao, P. P. and Ramachandraiah, D. (2004), "Performance of Broilers on 
Sorghum based diets", International Sorghum and Millets Newsletter, Vol. 45, pp. 37-40.

Tyagi, P. K., Elangovan, A. V, Mandal, A. B., Tyagi, P. K., Kaur, S. and Johri, A. (2003), "Effects of feeding low tannin sorghum grain to broiler chickens", Indian Journal of Animal Nutrition, Vol. 20 No. 3, pp. 322326.

Warle, B. M., Riar, C. S., Gaikwad, S. S., Mane, V. A. and Sakhale, B. K. (2015), "Effect of germination on nutritional quality of sorghum", International Journal of Current Research, Vol. 7 No. 5, pp. 16029 16033.
Yang, R., Wang, P., Elbaloula, M. F. and $\mathrm{Gu}, \quad$ Z. (2016), "Effect of germination on main physiology and biochemistry metabolism of sorghum seeds", Bioscience Journal, Vol. 32 No. 2, pp. 378-383.

Younis, D. T., Abdullah, F. A. and Abdulrahman, S. Y. (2012), "Effect of using germinated sorghum in physiological and productive performance of two quail strains", Mesopotamia Journal of Agriculture, Vol. 40 No. 4, pp. 14115. 